\title{
EXPLORING THE POSSIBILITIES OF PLASTINATION TECHNIQUES AND THEIR APPLICATION TO THE PRESERVATION OF THE ANATOMICAL PREPARATIONS
}

\author{
A. Georgieva*, J. Stoyanov, D. Sivrev \\ Department of Anatomy, Faculty of Medicine, Trakia University, Stara Zagora, Bulgaria
}

\begin{abstract}
Following the introduction of plastination there new possibilities for preservation of anatomical preparations in anatomical practice. Internal organs, limbs and parts of the trunk are treated with classical plastination methods S10, but P40 plastination technique is used for the production of brain plates with preserved features of the anatomical structure of the brain.

The main qualities of plastination technologies are: long-term preservation and absolute safety of made anatomical preparations for human health. Introduction in medical training in human and veterinary medicine of plastinated anatomical preparations will improve the quality of education in conditions of safety training.
\end{abstract}

Key words: plastination, Biodur, safety anatomical preparations, medical education

\section{INTRODUCTION}

In 1979 von Hagens, after many years of attempts, was able to make durable anatomical preparations, and a few years later he and al. (1), published their results. The first successful preparations were obtained by treatment of human or animal bodies with thermosettings resins and elastomers (2). Later he used silicone impregnation of previously dehydrated biological material for producing of safe, durable and elastic anatomical preparations (3). In classic S10 plastination technique originally tissue fluids shift to drier (4), and it is replaced by Biodur in terms of reduced atmospheric pressure (5). Plastination method is rapidly spreading worldwide. Numerous researchers bring it in practice, constantly improve and use it in their teaching practice $(6,7,8)$. This process continues today too (9). Special contribution to the improvement of plastination method has the American explorer Robert Henry, who introduces new elements in each stage of S10 plastination method $(4,5,10)$. In the beginning of the 90' years of the XX century, von Hagens (3) provides for the preservation of brain plates be used polyester co-polymers. Initially, he and other researchers

\footnotetext{
*Correspondence to: Dr Antoaneta Georgieva, Department of Anatomy, Faculty of Medicine, Trakia University, Stara Zagora 6000, Bulgaria, e-mail: tonrudeva_61@abv.bg
}

apply P35 plastination equipment $(11,12)$, which later develop and use the newer P40 materials $(13,14)$. According Ulfig (15) at P35 plastination method brain sections must first be contrasted by using color. For this purpose, the author uses astra blue color. Suriyaprapadilok and Withyachumnarnkul offer prior staining brain slices too (16). Weber accepts that the use of Biodur P40 is not necessary prior contrasting brain sections (17).

Nowadays plastination techniques are used for making of anatomical and pathological preparations in humans and animals $(18,19)$. Optimization of individual stages of plastination process continues $(20,21)$.

\section{AIM AND PURPOSES}

The purpose of this study was to trace possibilities of plastination techniques and their ability for preservation of anatomical preparations.

To realize this aim we set ourselves the following tasks:

Tracing the literature of test method.

Sharing his own experience in plastination of anatomical preparations.

\section{MATERIAL AND METHODS}

In the Laboratory for plastination of anatomical preparations in Medical Faculty Stara Zagora generally use a mixture of Biodur 
$\mathrm{S} 10 / \mathrm{S} 3$ in ratio $99: 1$ and Biodur $\mathrm{P} 40$ (Biodur ${ }^{T M}$, Heidelberg, Germany).

Methods that apply are two. S10 plastination method is used mainly for plastination of internal organs in humans and animals.

With plastination P40 method are produced brain plates with high contrast between gray and white matter of the brain.

\section{RESULTS}

With the Implementation of S10 plastination equipment are received anatomical preparations with high quality and consistency preserved, but with changed color.

Brain plates made by $\mathrm{P} 40$ plastination method are $4 \mathrm{~mm}$ thick and are reserved details of brain structure.

\section{DISCUSSION}

With S10 platination method made anatomical preparations of internal organs, limbs, head and neck, and parts of humans and animals torso. This is consistent with results presented by other authors $(1,7)$. Structures of the nervous system are plastinated by other authors $(11,12)$, but we never met data for the making of brain plates with S10 plastination technique. The probable reason for the lack of such experiments is the low mechanical stability of brain preparations. Here, as in other plastination laboratories, best results are obtained in internal organs plastination. The anatomical preparations successfully are used for medical students education. This statement is supported by all scientists from different countries of all over the world $(6,7,9,11,18)$.

Brain plates made by $\mathrm{P} 40$ plastination method are hard, semitransparent and resistant to mechanical damage. This is consistent with data published by other researchers $(12,13$, 17). In contrast to P35 method, P40 plastination technique does not require of prior staining of the brain, to obtain contrast between the gray and white matter $(12,17,22)$.

Anatomical preparations manufactured by plastination methods, in contrast to formalin preparations, are safe for human health.

\section{CONCLUSIONS}

1. Plastination methods are recommended for the manufacture of safe anatomical preparations.

2. Plastination anatomical preparations are suitable for training of medical students and related disciplines.

\section{REFERENCES}

1. Von Hagens, G., K. Tiedmann, W. Kriyz. The current potential of plastination. Anatomy and Embryology, 175(4): 411421, 1987.

2. Von Hagens, G. Impregnation of Soft Biological Specimens with Thermosettings Resins and Elastomers. Anatomical research, 194(2): 247-255, 1979.

3. Von Hagens, G. Heidelberg Plastination Folder. University of Heidelberg. 1991.

4. Hemry, R. Plastination - Dehydration of specimens. J Int Soc Plastination, 6(1): 4, 1992.

5. Hemry, R. Principles of Plastination Forced impregnation. $J$ Int Soc Plastination, 9(1): 26, 1995.

6. Mansor, O. Use of plastinated specimens in a medical school with a fully integrated curriculum. J Int Soc Plastination, 11: 1617, 1996.

7. Crabill, E., C. Saracco. The use, abuse and survival of plastination dissections in teaching head and neck anatomy. J Int Soc Plastination, 9(1): 16-17, 1995.

8. Dahmer, G. Demonstration of vascular anatomy in Plastination. $J$ Int Soc Plastination, 9(1): 17-18, 1995.

9. Latorre, RM, García-Sanz MP, Moreno M, Hernández F, Gil F, López O, Ayala MD, Ramírez G, Vázquez JM, Arencibia A, Henry RW. How useful is plastination in learning anatomy? J Vet Med Ed, 34: 172176, 2011.

10.Hemry, R. Principles of Plastination - Gas curing (Hardening). J Int Soc Plastination, 1995, 9(1): 13.

11. Weiglein, A. Plastinated brain specimens in the anatomical curriculum at Graz University. J Int Soc Plastination, 7(3): 3-7, 1993.

12.Weiglein, A., G. Feigl. Sheet plastination of brain slices and according to the P35 and P40 procedures. J Int Soc Plastination, 13(2): 30, 1998.

13.Sora, M., P. Brugger, H. Traxler. P40 plastination of Human brain slices: Comparison between different immersion and impregnation conditions. J Int Soc Plastination, 1999, 14(1): 22-24.

14.Steinke, H., S. Pfeiffer, K. SpanelBorowski. A new plastination technique for head slices containing brain. Annals of Anatomy, 2002, 353-358.

15.Ulfig, N. Staining of human fetal and adult brain slices combined with subsequent plastination. J Int Soc Plastination, 1990, 4(1): 33-38.

16. Suriyaprapadilok L, Withyachumnarnkul B. Plastination of stained sections of the 
human brain: Injection Plastination 17. Comparison between different staining methods. J Int Soc Plastination, 1997, 12(1): 27-32.

17. Weber, W. Sheet plastination of brain slices. J Int Soc Plastination, 1994, 8(1): 23.

18. Hermes B. Plastination an additional tool to teach anatomy. Int J Morphol, 2006, 24:475-480.

19.B.A. Mendez, B., R. Romero, F. Trigo, R. Henry, A. Candanosa. Evaluation of Imidazole for Color Reactivation of Pathological Specimens of Domestic
Animals. J Int Soc Plastination, 2008, 23:17-24

20.Brown, M., R. Reed, R. Henry. Effects of dehydration mediums and temperature on total dehydration time and tissue strinkage. J Int Soc Plastination, 2002, 17: 28-33.

21. Sakamoto Y, Miyake Y, Kanahara K, Kajita K, Ueki H. Chemically reactivated plastination with Shin-Etsu silicone KE108. J Int Soc Plastination, 2006,21: 11-16.

22.Henry RW. Polyester plastination technique: Specific troubles and problems. J Int Soc Plastination, 2006, 21:31. 